\title{
DAKWAH INTERAKTIF KULTURAL EMHA AINUN NADJIB
}

\section{CULTURAL INTERACTIVE DA'WAH EMHA AINUN NADJIB}

\author{
Rio Febriannur Rachman \\ Institut Agama Islam Syarifuddin Lumajang \\ Email : riofrachman21@gmail.com
}

\begin{abstract}
Emha Ainun Nadjib or Cak Nun is one of Indonesian Muslim intellectuals who have published best-seller books and lectured at many places in Indonesia and also the other countries. He uses interesting da'wah method which successfully making him popular in many societies. Cak Nun implements interactive communication techniques and cultural approaches, then what he says can be accepted by the public. Cak Nun builds intimacy, so the listeners feel emotional bond with him. Cak Nun da'wah activities through the Maiyah forum have been carried out over the years, with the growing number of listeners. His lecture material encompass many topics, and still in line with religiosity. Until now, the platform used is not only offline, but also strengthened through the website www.caknun.com, which is connected with youtube channel. Documentation of da'wah activities is not only done by that official website, but also by other parties who think that saving and disseminating the content of Cak Nun da'wah is needed. Then, those are shared through social media.
\end{abstract}

Keywords: Cak Nun, Maiyah, Da'wah, Interactive, Cultural

\begin{abstract}
ABSTRAK
Emha Ainun Nadjib atau Cak Nun merupakan salah satu intelektual muslim Indonesia yang sudah menerbitkan buku-buku best seller maupun berceramah di banyak tempat di dalam maupun luar negeri. Metode dakwah yang dilakukan Cak Nun sukses membuatnya disukai banyak kalangan di masyarakat. Cak Nun menerapkan teknik komunikasi interaktif dan pendekatan kultural sehingga apa yang dia sampaikan bisa diterima oleh publik. Cak Nun membangun keakraban sehingga para pendengar merasa memiliki ikatan emosional dengannya. Aktifitas dakwah Cak Nun melalui forum Maiyah telah dilakukan selama bertahun-tahun dengan jumlah pendengar yang semakin berkembang. Materi ceramahnya menyentuh banyak topik dengan tidak meninggalkan muatan religiositas. Hingga saat ini, platform yang digunakan tidak hanya offline, namun juga diperkuat melalui website www.caknun.com yang terkoneksi dengan kanal youtube. Dokumentasi kegiatan dakwah tidak hanya dilakukan website resminya, namun juga oleh pihakpihak lain yang merasa perlu menyimpan dan menyebarkan konten dakwah yang disampaikan melalui media sosial.
\end{abstract}

Kata-kata Kunci: Cak Nun, Maiyah, Dakwah, Interaktif, Kultural

ISSN 2338 - 0861 (cetak); e-ISSN 2621 - 8712 (online)

website : http://spektrum.stikosa-aws.ac.id 


\section{PENDAHULUAN}

Emha Ainun Nadjib yang dikenal dengan sebutan Cak Nun adalah salah satu intelektual muslim Indonesia. Walaupun dalam banyak kesempatan, dia berupaya menolak predikat-predikat semacam itu. Cak Nun selalu menyebut dirinya sebagai orang biasa yang suka berkawan dan bersaudara dengan semua orang. Faktanya, sejarah mencatat namanya sebagai pemikir yang memiliki banyak karya dan aksi-aksi positif di masyarakat. Pria kelahiran Jombang, 27 Mei 1953 ini, sudah menulis banyak buku. Sebagian adalah buku puisi atau syair-syair, yang beberapa di antaranya dijadikan lirik lagu bersama grup musik Kiai Kanjeng.

Ada banyak bukti yang bisa menunjukkan bahwa Cak Nun merupakan intelektual muslim. Di antaranya, bahwa karya-karya yang dibuat oleh suami Novia Kolopaking ini bermuatan religiositas bernuansa Islam. Cobalah tengok salah satu puisi karangannya berjudul "Seribu Masjid Satu Jumlahnya" (1987). Melalui puisi itu, dia menuturkan bahwa membangun masjid tidak hanya secara fisik, namun juga secara mental atau ruhani para jamaah. Selain itu, berapa pun masjid di dunia ini, muaranya tetap satu, pada Allah Subhanahu Wa Ta'ala. Berikut penggalan puisi tersebut, pada dua bait pertama dan dua bait terakhir.

(Dua bait pertama)
Satu
Masjid itu dua macamnya
Satu ruh, lainnya badan
Satu di atas tanah berdiri
Lainnya bersemayam di hati
Tak boleh hilang salah
satunyaa
Kalau ruh ditindas, masjid
hanya batu

Kalau badan tak didirikan, masjid hanya hantu

Masing-masing kepada Tuhan tak bisa bertamu

Dua

Masjid selalu dua macamnya

Satu terbuat dari bata dan

logam

Lainnya tak terperi

Karena sejati

(Dua bait terakhir)

Seribu masjid tumbuh dalam sejarah

Bergetar menyatu sejumlah

Allah

Digenggamnya dunia tidak dengan kekuasaan

Melainkan dengan hikmah kepemimpinan

Allah itu mustahil kalah

Sebab kehidupan senantiasa lapar nubuwwah

Kepada berjuta Abu Jahl yang menghadang langkah

Muadzin kita selalu mengumandangkan Hayya

'Alal Falah!

Sementara itu, salah satu syair yang dijadikan lirik lagu berjudul Ya Ampun (2000) disenandungkan Cak Nun bersama Kiai Kanjeng. Dalam lirik lagu itu, dia banyak menyitir nama nabi-nabi berikut mukjizatmukjizat merek. Dia juga terangterangan berdo'a pada Allah Subhanahu Wa Ta'ala. Berikut adalah tiga bait pertama dan tiga bait terakhir dari lirik lagu tersebut, sebagai contoh.

(Tiga bait pertama) Ya ampun lalimnya manusia ya ampun bebalnya penguasa ya ampun tuli telinganya ya ampun dusta politiknya

Ya Allah Ayyubkan hamba

ISSN 2338 - 0861 (cetak); e-ISSN 2621 - 8712 (online) website : http://spektrum.stikosa-aws.ac.id 
Ya Allah lebarkan dada

Ya Allah...Ya Allah... Ya Allah luaskan jiwa...

(Tiga bait terakhir) ya Allah...ya Allah... ya Allah Khaliqul anam

Sungguh tidak tega kubalas seluruh cinta mati hidup hamba untuk tangis mereka

\section{Ya Allah Muhammadkan hamba taburkanlah syafa'atnya ya Allah...ya Allah... agar terkuak rahasaia surga...}

Sebagai seorang intelektual muslim yang produktif, dia memiliki banyak karya. Dia juga berkolaborasi dengan grup music Kiai Kanjeng untuk menyenandungkan sholawat di berbagai panggung di setiap pelosok tanah air. Apalagi, saat ini dia juga rutin melakukan dakwah atau menyampaikan pesan-pesan keislaman. Dakwah merupakan suatu aktifitas yang harus ditunaikan setiap muslim. Ia dapat dilakukan dalam bentuk seruan, pemberian contoh ahlak yang mulia, dan kegiatankegiatan yang bermashlahat bagi setiap insan (Abidin, 1996).

Cak Nun melakukan dakwah melalui pengajian-pengajian yang dikenal dengan sebutan Forum Maiyah, sedangkan mereka yang ikut dalam pengajian ini disebut Jamaah Maiyah. Forum Maiyah yang dalam terjemah bebas berarti kebersamaan, dilaksanakan satu bulan sekali di sejumlah kota. Di beberapa lokasi, forum ini memiliki nama sesuai kultur dan kearifan lokal. Misalnya, di Surabaya disebut Bang-Bang Wetan, di Jombang disebut Padhang Mbulan, di Yogyakarta disebut Mocopat Syafaat, di Jakarta disebut Kenduri Cinta, di Malang disebut Obor Ilahi, di Makassar disebut Paparandeng Ate, dan sebagainya. Maiyah juga acap dilaksakan di kota-kota lain yang waktunya tentatif (Rachman, 2016).

Selain Cak Nun, forum ini juga disemarakkan oleh grup music Kiai Kanjeng. Yang dalam penampilannya, selalu memunculkan lagu-lagu bernafaskan islam, sebagai contoh, lagu-lagu dengan lirik sholawat. Kolaborasi antara Cak Nun dan Kiai Kanjeng dalam Forum Maiyah saat ini telah memiliki jamaah yang berjumlah banyak. Terbukti, di banyak kota, dalam rentang tahun yang lama, kegiatan ini telah diterima masyarakat. Bukti lain kalau Cak Nun merupakan sumbu yang menjadi salah satu poros dalam dunia keislaman di Indonesia adalah semaraknya video-video yang bersangkutan di dunia maya, dalam hal ini kanal www.youtube.com. Pengunggahnya tidak hanya dari pihak Cak Nun, melalui website resmi www.caknun.com. Melainkan, dan ini yang lebih banyak, dari pengunggahpengunggah lain yang adalah penyuka video-video tersebut. Artinya, dalam rentang yang sudah cukup lama, Cak Nun berkiprah di dunia nyata maupun di dunia maya.

Artikel ini akan menelaah sejumlah keunikan dari model dakwah Cak Nun, melalui rangkaian video yang dilansir oleh www.caknun.com, berjudul Angkasa Pura Surabaya. Video ini dipilih sebagai karena merupakan video terpanjang yang ada di website tersebut. Video itu diambil saat Cak Nun berceramah di Surabaya pada 24 Februari 2017. Video ini terdiri tiga file namun bersambung menjadi satu kesatuan. File pertama berdurasi 01.25.28, kedua berdurasi 01.15.25, 
dan ketiga 01.25.15. Sehingga, panjang video secara keseluruhan adalah 04.06.08 atau empat jam, enam menit, delapan detik.

\section{METODOLOGI}

Riset ini menggunakan metode kualitatif, menganalisis konsep dan data, berupa bahan visual dari video Cak Nun yang sudah dipilih, guna menghasilkan penjelasan deskriptif. Pendekatan yang digunakan adalah analisis visual. Pendekatan ini memiliki tiga pembagian area penelitian visual berdasar posisi sudut pandang.

Rose dalam Ida (2011) menyebutkan, tiga posisi tersebut adalah sit of self, site of production, dan site of audience. Posisi yang diambil dalam riset ini adalah sit of self. Jadi, penulis melakukan intrepretasi, pemaknaan, dan pemahaman akan objek yang diamati. Peneliti menggunakan kemampuan analisis kritis untuk membaca dan mengurai makna komposisikomposisi yang ada di objek visual. Khususnya, sehubungan dengan model dakwah Cak Nun.

\section{HASIL DAN PEMBAHASAN}

Cak Nun dan Kiai Kanjeng kerap memulai aksi panggung mereka dengan menyenandungkan lagu-lagu. Khususnya, lagu sholawat. Dalam event di lapangan Angkasa Pura Surabaya, 24 Februari 2017, lagu yang kali pertama digemakan di hadapan hadirin adalah Sholawat Badar, yang syairnya ditulis oleh KH Ali Mansur Shiddiq pada tahun 1962. Alunan sholawat makin bergemuruh karena para hadirin juga ikut melantunkan pujian-pujian tersebut. Kebiasaan menyenandungkan sholawat di atas panggung tidak hanya di awal kegiatan, namun juga kerap dilaksanakan di sela acara sebagai pengisi waktu. Antara lain, pada menit ke 08.40 di video pertama.

Dalam kesempatan itu, Cak Nun tidak sendirian di atas panggung. Selain, para personel Kiai Kanjeng yang selalu bersiap di sisi belakang, di atas panggung, dengan masingmasing alat musik, terdapat pula jajaran pejabat tinggi Angkasa Pura Surabaya, yang menjadi pihak pengundang pengajian Cak Nun kali ini. Forum Maiyah, selain diadakan secara rutin di banyak kota tanpa melalui undangan tertentu, juga bisa dilaksanakan pada momen-momen tertentu berdasarkan undangan. Meski demikian, ada atau tidak ada undangan di suatu kota, tidak lantas mengganggu jadwal kehadiran Forum Maiyah di kota-kota yang sejak dulu sudah rutin menggelar acara ini.

Kegiatan dakwah adalah kegiatan komunikasi tatkala da'i (komunikator) mengomunikasikan pesan kepada mad'u (komunikan), baik secara perseorangan maupun kelompok. Semua hukum yang berlaku dalam ilmu komunikasi berlaku juga dalam dakwah, hambatan komunikasi adalah hambatan dakwah, dan bagaimana mengungkapkan apa yang tersembunyi di balik perilaku manusia dalam berdakwah, sama juga dengan apa yang harus dikerjakan pada saat manusia berkomunikasi (Ilahi, 2010).

Yang menarik, dalam dakwahnya, Cak Nun tidak memosisikan diri secara mutlak sebagai penyampai pesan. Namun juga, memersiapkan diri sebagai penerima pesan. Dengan demikian, muncul interaksi melalui percakapan yang sering kali terjadi secara spontan, tanpa sekat karena sudah akrab, dan diselingi guyonan segar. Meskipun kalimat-kalimat interaktif

ISSN 2338 - 0861 (cetak); e-ISSN 2621 - 8712 (online)

website : http://spektrum.stikosa-aws.ac.id 
itu tidak selalu menjadikan konten religiositas sebagai sumbunya, karena kadang interaksi yang dilakukan sekadar canda, tetap saja apa yang dilakukan Cak Nun bisa membangun kedekatan. Sehingga, hadirin atau para penerima pesan menyukainya, yang pada satu titik, lebih gampang menangkap dan percaya pada apa yang disampaikannya.

Rakhmat (1994) menuturkan, bila penampilan orang sudah meyakinkan pada satu disiplin ilmu tertentu, orang lain akan percaya pada apa yang dia sampaikan. Cak Nun tidak bermain di ranah penampilan yang sifatnya fisik, seperti pakaian atau atribut artifisial keagamaan seperti sorban dan jubah. Namun, dia menempatkan dirinya sebagai orang yang memiliki retorika baik dan interaktif, sehingga hadirin atau penerima pesan merasa dekat dengannya. Muaranya, mereka nyaman dengan interaksi yang terjadi. Interaksi antara Cak Nun dan hadirin, antara lain, dapat disaksikan pada menit ke 00.04.00 di video pertama. Cak Nun menyampaikan kalimat yang ditujukan baik bagi para hadirin, maupun bagi para petinggi Angkasa Pura Surabaya yang ada di atas panggung.

"Arek-arek neng ngarepku iki, Pak, sing mene-mene sing dadi GM (Orang-orang di depan saya ini, Pak, yang besok-besok menjadi General Manager di Angkasa Pura Surabaya)"

Kata "Orang-orang" yang dikatakan Cak Nun merujuk pada para hadirin yang terdiri dari Jamaah Maiyah dari berbagai kota di Jawa Timur dan sekitarnya, yang pada malam itu berkunjung untuk menyaksikan Forum Maiyah. Sedangkan kata sapa "Pak" merujuk pada Bapak-bapak para pejabat Angkasa Pura Surabaya. Ada interaksi antara da'i atau komunikator, dalam hal ini Cak Nun, dengan mad'u atau komunikan, dalam hal ini hadirin baik yang ada di atas panggung maupun tidak.

Interaksi serupa dapat dilihat pada menit ke 00.04.57 di video pertama. Cak Nun menyampaikan pada para hadirin yang waktu itu tampak kesulitan untuk melihat panggung. Khususnya, para hadirin yang berada di belakang salah satu juru kamera.

"Kameramene kon ndodok ae iku. Neng cagak (Juru kamera suruh duduk saja itu di tiang)"

Terjadi interaksi antara Cak Nun yang memberi saran pada hadirin yang berada di belakang juru kamera, agar mereka menyuruh juru kamera duduk di salah satu sudut tiang yang ada di area tersebut. Dengan demikian, mereka yang berada di belakang kamera tersebut tidak terganggu pandangannya ke atas panggung.

Baik setelah menit 00.04.00 maupun setelah menit 00.04.57, para komunikan atau mad'u yang mendengar pesan dari Cak Nun menyambutnya dengan tawa berderai. Artinya, terdapat interaksi positif di dalamnya. Tak ada yang tersinggung dengan ucapan Cak Nun yang bisa jadi di luar konteks awal diskusi Forum Maiyah yang umumnya membahas persoalan sosial di masyarakat. Sebaliknya, suasana menjadi lebih nyaman sehingga komunikasi bisa berjalan lebih lancar. Bahkan, dalam rekaman video berjudul Angkasa Pura Surabaya itu, Forum Maiyah berlangsung hingga empat jam, enam menit, delapan detik. Tentu saja, ada bagian faktual

ISSN 2338 - 0861 (cetak); e-ISSN 2621 - 8712 (online)

website : http://spektrum.stikosa-aws.ac.id 
yang diedit saat masuk menjadi kesatuan video dalam tiga bagian tersebut. Sehingga sudah barang tentu, durasi Forum Maiyah kali itu jauh lebih lama.

Komunikasi interaktif seperti yang disampaikan di atas terjadi berulang kali. Misal lain dapat dilihat pada menit ke 00.06.55 video kedua.

"Iki sing nang kene menejer kabeh, Rek. Gak koyok dapuranmu. Lhah tapi yo koen isok ngomong jugak, lhah terus Cak Nun iku opo (Ini yang ada di panggung kelas manajer atau pejabat tinggi semua. Tidak seperti kalian. Tapi kalian ya juga bisa bilang, terus Cak Nun itu siapa?)"

Di satu sisi, Cak Nun terdengar mengejek para hadirin di hadapan para petinggi Angkasa Pura Surabaya. Di sisi lain, Cak Nun juga mengejek dirinya sendiri baik di hadapan para petinggi Angkasa Pura, maupun di hadapan para hadirin. Apa yang dilakukan Cak Nun sejatinya hendak menyamakan dirinya dengan para hadirin sekalian. Bahwa dia tidak jauh beda dibandingkan mereka. Yang jelas, kalimat yang disampaikan tersebut menunjukkan keinginan Cak Nun membuat ruang interaksi yang egaliter dengan para hadirin.

Cak Nun selalu berupaya membangun kedekatan dengan hadirin para pendengar. Dia tidak ingin kehilangan momentum keakraban, sehingga komunikan atau pihak yang menerima pesannya lebih mudah merespon apa yang dikomunikasikan secara positif. Selain membangun interaksi dengan hadirin atau jamaah, Cak Nun berusaha menyentuh nilai-nilai kultural. Penggunaan bahasa atau istilah Surabaya saat berdakwah di
Surabaya, adalah cermin betapa dia ingin merasuk atau menyatu dengan jamaah yang hadir di lapangan Juanda malam itu.

Pada video pertama di menit 00.21 .00 sampai 00.22 .00 , misalnya, dia berbicar tentang nasib petugas bandara Juanda para tukang dorong barang. Yang mungkin saja, seumur hidup tidak pernah naik pesawat. Dalam rentang menit tersebut pula, Cak Nun berkisah tentang Gus Dur yang kemungkinan, kelakar Cak Nun, sampai sekarang belum ditanyai oleh malaikat Munkar Nakir di alam kubur. Penyebabnya, sejak wafat sampai saat ini, makam Gus Dur tidak pernah sepi pelayat.

"Gus Dur iku sampek saiki sik gurung urusan, Rek. Makane ta, koen nek pengen urusanmu neng alam kubur ndang mari, sesuk nek mati sing ngelayat gak usah akehakeh (Gus Dur itu sampai sekarang belum berurusan (berurusan dengan malaikat terkait pertanyaan alam kubur, pen. Maka itu, kalau kalian ingin urusan lekas selesai, nanti kalau kalian mati yang melayat tidak usah banyak-banyak orang)"

Ada dua poin yang menunjukkan adanya upaya mendekati khalayak secara kultural. Pertama, Cak Nun memberikan contoh kisah tentang petugas di Bandara Juanda, bandara yang merupakan salah satu ikon Surabaya. Sehingga, ikon yang dimaksud berpotensi membangun kedekatan dengan orang-orang Jawa Timur yang datang dalam acara itu. Kedua, Cak Nun bercerita tentang Gus Dur, salah satu tokoh asal Jawa Timur yang memang populer dan memiliki basis massa besar di provinsi ini.

Pada video ketiga di menit 1.04.06 sampai 1.08.00, Cak Nun website : http://spektrum.stikosa-aws.ac.id 
bicara tentang model-model bersalaman yang sering dia jumpai saat berkunjung ke banyak kota. Bahkan, di luar negeri seperti Malaysia. Ada yang bersalaman biasa, sambil mencium tangan, berpelukan dan menempelkan pipi kanan dan pipi kiri, bahkan ada orang yang setelah bersalaman minta ditempeleng. Ada juga yang saat bersalaman, tangan Cak Nun diusapkan ke kepala dan badannya. Terdapat pula yang memeluk lalu menggigit dada, bahkan menggigit pipi.

Meski demikian, Cak Nun mengaku tidak memermasalahkan itu. Dia tidak pernah marah, bahkan berteriak. Semua itu membuktikan, Cak Nun tidak ingin perbedaan model bersalaman, atau perbedaanperbedaan lain di banyak wilayah, membuat dia tidak bisa akrab dengan khalayak. Sebaliknya, dia mencoba tetap membaur dan berempati dengan kebiasaan atau gaya interaksi semua orang.

Tentu saja, ada banyak penggalan video lain sehubungan dengan lagah Cak Nun melakukan pendekatan kultural dalam dakwahnya. Sebagai contoh, masih di video ketiga pada menit yang lain, tepatnya di menit 01.11.00. Dalam kesempatan itu, Cak Nun menjelaskan tentang pentingnya memberi ruang empati, simpati, atau pengertian terhadap beraneka kultur yang ada di masyarakat. Dia mencontohkan, di Surabaya dan sebagian daerah di Jawa Timur yang memiliki kultur "Arek", mengumpat atau misuh dengan bahasa daerah tidak selalu simbol pertengkaran atau kalimat dengan muatan negatif. Justru, bisa menjadi simbol kemesraan.

Cak Nun mengatakan, seseorang harus datang dulu ke Surabaya, untuk merasakan kemesraan dari misuh tersebut. Melalui ucapannya tersebut,
Cak Nun ingin membongkar ruang eksklusifitas dalam wacana yang berkembang di pemahaman sebagian masyarakat. Cak Nun mengajak setiap orang untuk memahami dulu kondisi orang lain, dalam hal ini kultur atau budaya orang lain, sebelum memberi penilaian apakah yang dilakukannya baik atau buruk. Di sisi lain, ini merupakan bukti kalau Cak Nun memiliki wawasan terbuka dan selalu berupaya maklum dengan kearifan lokal atau kebiasaan di setiap tempat. Tentu, asalkan tidak masuk ke ranah dosa dan kriminalitas.

Sentuhan kultural yang diterapkan Cak Nun membuat hadirin tersentuh jiwanya. Cak Nun menembus aspek-aspek psikologi hadirin. Sehingga, apa yang disampaikannya bisa meresap pada pikiran penerima pesan, atau jamaah. Yang pada satu titik, membuat penerima pesan puas kehidupan rohaninya. Di sinilah letak fokus strategi dakwah yang sebenarnya, yaitu bisa membuat mereka yang diajak ke jalan yang benar, bersedia dengan tulus mengikuti jalan tersebut (Mubarok, 1997).

\section{KESIMPULAN}

Cak Nun adalah seorang
pendakwah yang berupaya dekat
dengan masyarakat.
menyampaikan sederhana. Memberikan gagasan yang gampang diterima dan mudah dipahami khalayak. Dia menggunakan teknik komunikasi interaktif yang memungkinkan massa langsung merespon apa yang dia ungkapkan. Respon berupa tawa, sorakan, dan tepuk tangan, adalah beberapa jenis reaksi yang bisa dipahami sebagai tanda bahwa massa mengerti dengan apa yang disampaikannya.

ISSN 2338 - 0861 (cetak); e-ISSN 2621 - 8712 (online)

website : http://spektrum.stikosa-aws.ac.id 
Pada forum Maiyah, hadirin dipersilakan untuk menyampaikan pertanyaan. Yang lantas dijawab oleh Cak Nun sendiri, ataupun oleh narasumber lain yang ada di atas panggung. Hadirin diberikan ruang seluas-seluasnya untuk menyampaikan pendapat. Suasana diskusi atau pengajian menjadi lebih luwes, nyaman, dan menyenangkan. Tak ayal, pengajian ini umumnya berlangsung berjam-jam, umumnya dimulai pukul 20.00 malam hingga pukul 02.00 dini hari (Saputra, 2012). Dalam rangkaian video yang dijadikan bahan pembahasan kali ini, sesi tanya jawab interaktif ini bisa dilihat di video ketiga.

Gaya komunikasi Cak Nun juga mengedepankan pendekatan kultural. Yakni, membawa nilai-nilai budaya atau kearifan lokal sebagai sarana dalam berdakwah. Memang, apa yang dia lakukan berbeda dengan yang dikerjakan para wali songo, yang di dalam sejumlah literatur disebutkan, memakai seni budaya musik tradisional maupun wayang, sebagai media dakwah.

Musik yang dimainkan Cak Nun tidak sepenuhnya tradisional. Kelompok Kiai Kanjeng yang mengiringinya memang memakai gamelan. Namun juga membawa organ/keyboard, dan gitar. Dan yang jelas, Cak Nun tidak membawa wayang. Jadi pendekatan kultural yang dimaksud di sini bukan tentang hal-hal tersebut. Melainkan, soal gaya bahasa yang dia sampaikan pada sasaran atau lawan bicara, maupun materi yang dikemukakannya, selalu berusaha selaras dengan budaya setempat.

Sebagai contoh, Cak Nun menggunakan bahasa dan istilah Surabaya, saat sedang berdakwah di Surabaya. Hal itu dapat dilihat dalam video-video yang menjadi bahan pembahasan kali ini. Dalam video lain, yang ada di banyak kanal youtube, tatkala berbicara di Jakarta, Cak Nun menggunakan bahasa dan istilah setempat. Demikian pula saat dia berada di daerah atau kawasan lain, kearifan lokal setempat yang akan dijadikannya sisipan dalam ceramah. Misalnya, saat berbicara di Yogyakarta, dia akan mengatakan betapa agungnya budaya di sana. Termasuk, soal keselarasan antara Gunung Merapi, Lau Selatan, dan Kerajaan Yogyakarta itu sendiri. Dengan cara itu, proximity atau kedekatan antara Cak Nun dan hadirin akan terbentuk.

Dalam banyak kesempatan, Cak Nun selalu menyampaikan tentang potensi besar alam Indonesia. Dia sedang membangun optimisme. Khususnya, pada umat Islam, walaupun hadirin yang datang ke forum Maiyah tidak melulu orang Islam. Bahkan, tak jarang orang berbeda agama diajak menjadi narasumber sebagai penambah wawasan serta referensi. Cak Nun selalu menyampaikan bahwa Indonesia merupakan masyarakat majemuk dan beragam, yang semua suku-sukunya memiliki keunikan dan kekuatan. Sinergitas adalah harga mati untuk membawa kemajuan di bumi pertiwi ini.

Pada menit ke 00.18 .00 sampai 00.18.40 di video kedua dalam bahan pembahasan kali ini, misalnya, Cak Nun menyampaikan tentang keluhuran dan kehebatan Indonesia. Dengan menggunakan bahasa Indonesia dan intonasi suara yang stabil, Cak Nun mengemukakan pandangannya.

“ (bangsa) Indonesia itu kalau dia percaya diri dan tahu jatidirinya sendiri, maka Indonesia itu betulbetul merupakan kelengkapan 
makhluk dan bangsa, yang paling unggul dan bisa memimpin dunia.....kita itu unggul segalagalanya. Dan salah satu keunggulan kita yang terpenting adalah kita tidak ingin menggungguli siapa-siapa,"

Sejauh ini referensi tentang intelektual muslim di Indonesia sudah banyak. Namun, masih belum banyak literatur yang membahas tentang Cak Nun. Padahal, pemikir yang satu ini tergolong budayawan muslim yang memiliki beraneka karya. Baik itu yang tertulis, maupun yang terlontar melalui ceramah-ceramahnya dalam forum resmi. Bahwa Cak Nun tidak memiliki gelar kesarjanaan formal, tentu seharusnya tidak menjadi kendala untuk membahas figur ini dengan lebih serius. Sebab, tidak bisa dimungkiri, pengaruh Cak Nun ke banyak kalangan tidak bisa dibilang kecil.

Cak Nun memiliki basis penggemar yang dapat dilihat dari lautan jamaah Maiyah dalam banyak kegiatan yang diikutinya. Di kanal youtube, namanya sering menjadi kata kunci, yang kerap konten videonya diberi komentar positif, disukai, dan dibagikan pada sesama warganet. Tulisan-tulisannya pun, selain dicetak ulang melalui bukubuku, juga kerap diberi komentar positif, disukai, dan dibagikan di dunia maya. $\left(^{*}\right)$

\section{DAFTAR PUSTAKA}

Achmad, Mubarok. 1997. Psikologi Dakwah Jakarta : Pustaka Firdaus.

Djamalul, Abidin. 1996. Komunikasi dan Bahasa Dakwah, Jakarta: Gema Insani Pres.

Ida, Rachmah. 2011. Metode Penelitian Kajian Media dan
Budaya. Surabaya: Airlangga University Press.

Saputra, Prayogi R. 2012. Spiritual Journey, Pemikiran \& Permenungan Emha Ainun Nadjib. Jakarta: Kompas.

Rakhmat, Jalaluddin. 2005. Psikologi Komunikasi, Bandung: Remaja Rosdakarya.

Wahyu, Ilahi. 2010. Komunikasi dakwah, Bandung: Remaja Rosdakarya.

ISSN 2338 - 0861 (cetak); e-ISSN 2621 - 8712 (online) website : http://spektrum.stikosa-aws.ac.id 